\title{
АНАЛІЗ ЕФЕКТИВНОСТІ АЛОКІНУ-АЛЬФА У СКЛАДІ КОМПЛЕКСНОЇ ТЕРАПІЇ РЕЦИДИВНОГО ОПЕРІЗУВАЛЬНОГО ГЕРПЕСУ
}

\author{
ВДНЗ України «Буковинський державний медичний університет»
}

\begin{abstract}
Мета роботи - вивчення терапевтичної ефективності нового імунотропного препарату «Алокінальфа», діючою речовиною якого є читокіноподібний пептид алофрерон, у складі комплексної терапії рецидивного оперізувального герпесу у ВІЛ-інфікованих і хворих без імунодефіциту.

Пацієнти і методи. Загальне число обстежених і пролікованих хворих на рецидивний оперізувальний герпес склало 56 людей, із них 16 ВІл-інфрікованих і 40 хворих без імунодефріциту. Для репрезентативної вибірки хворі були поділені на чотири групи. До першої основної групи було включено 19 імунокомпетентних хворих на оперізувальний герпес, до другої основної8 ВІл-інфрікованих хворих з оперізувальним герпесом. Цим особам на фроні базисної терапії (щоденний прийом етіотропного засобу з міжнародною непатентованою назвою (МНH) валацикловір - 1,0 г всередину 2 рази на день впродовж 10-14 діб, з переходом на супресивну терапію по 0,5 г 2 рази на день впродовж 1 міс.) додатково призначали 3 підшкірні ін'єкції імунотропного препарату алокін-альфра (алоферон), в дозі 1 мг через день. Першу і другу групу контролю склали 21 і 8 пацієнтів відповідно, яким призначали тільки зазначену базисну терапію.
\end{abstract}

Результати. На підставі дослідження клінічних показників встановили, що тільки базисна терапія не забезпечує вагомого клінічного ефекту.

Доповнення базисного лікування 3 підшкірними ін'єкціями алокіну-альфра забезпечує скорочення тривалості клінічних проявів оперізувального герпесу у хворих без імунодефріциту порівняно з терапією тільки валацикловіром $(P<0,05)$.

Поряд зі зменшенням частоти рецидивів після застосування апробованого цитокіноподібного препарату статистично вагомо скорочувалась й тривалість першого рецидиву ВІЛ-асоційованого оперізувального герпесу після лікування, вона становила $(7,0 \pm 0,6)$ доби. У пацієнтів, лікованих лише валацикловіром, чей показник склав $(11,3 \pm 0,5)$ доби $(p<0,05)$.
Відповідне амбулаторне спостереження за пацієнтами у III-IV клінічній стадії ВІЛ-інфрекції, які отримали тільки базисну терапію оперізувального герпесу, також не виявило якого-небудь впливу на частоту рецидивів ( $p>0,05)$. Доповнення ж базисної терапії апробованим цитокіноподібним препаратом забезпечувало збільшення тривалості ремісії і зменшення частоти рецидивів оперізувального герпесу - від $(1,60 \pm 0,24)$ до $(0,60 \pm 0,24)$ разу на 3 міс. $(p<0,05)$.

Також поряд зі зменшенням частоти рецидивів ВІЛ-асоційованого оперізувального герпесу у пацієнтів з III-IV клінічною стадією після застосування апробованого цитокіноподібного препарату вагомо скорочувалась й тривалість першого рецидиву після лікування - $(9,8 \pm 0,4)$ і $(16,3 \pm 0,6)$ доби відповідно $(p<0,05)$.

Висновки. Доповнення базисного етіотропного лікування оперізувального герпесу імунотропним препаратом алокін-альфа забезпечує скорочення тривалості клінічних проявів під час лікування, тривалості першого рецидиву після лікування, а також зменшення частоти рецидивів як у ВІЛ-інфікованих, так і у хворих без імунодефріциту.

Ключові слова: ВІЛ-інфекція, оперізувальний герпес, лікування, алокін-альфра.

У сучасній інфектології герпесвірусні інфекції (ГВІ) посідають одне з провідних місць як за різноманітністю клінічних фрорм, так і за складністю діагностики та лікування. За даними ВООЗ, від 65 до 90 \% населення Землі інфіковано одним або кількома типами герпесвірусів (ГВ), а від ГВІ з рецидивами потерпають у різних країнах від 2 до 12 л людей [1, 2]. Інфрікованість і захворюваність на ГВІ щороку зростає, подібна несприятлива тенденція помічена і в Україні [3]. Для всіх типів ГВ характерною $є$ здатність до тривалої персистенції в організмі людини з можливістю розвитку захворювань навіть після багаторічного латентного періоду. Найважливішими причинами такої невтішної динаміки можна вважати збільшення в структурі населення осіб з імуно- 
логічними порушеннями, в тому числі ВІЛ-інфікованих хворих $[4,5]$.

На сьогодні близько 34 млн жителів нашої планети уражені ВІЛ-інсрекцією. Найбільше постраждала Африка, дещо менше - Південно-Східна Азія, Америка та Європа [6]. За темпами розвитку епідемії ВІЛ-іноекції Україні належить сумне лідерство в Європі нарівні 3 Російською Федерацією та Естонією. У нашій країні, починаючи з 2000 р., неухильно зростало число нових випадків ВІЛ-інфекції [7]. Незважаючи на досягнення значного прогресу в протидії ВІЛ-іноекції/СНІДу, в умовах трансорормації усіх сорер життєдіяльності, економічної кризи та військового конфрлікту на сході країни, ВІЛінфекція в Україні продовжує поширюватись [8]. ВІЛінфрекція перебігає на тлі виразного імунодесріциту 3 прогресуючим зниженням кількості та фрункціональною недостатністю CD4+-лімфроцитів, що зумовлює розвиток інфекційних опортуністичних захворювань. Одним із найбільш поширених і тяжких опортуністичних захворювань у ВІЛ-інфікованих $є$ оперізувальний герпес (ОГ). Згідно з клінічним протоколом МОЗ України № 182 від 13.04.2007 р., хворим на рецидивний ОГ на тлі ВІЛінфекції призначають один з етіотропних протигерпетичних засобів - ацикловір, валацикловір або фамцикловір [9]. Але вищевказаний спосіб лікування не забезпечує тривалий клінічний та імунологічний ефрект, тому у хворих часто виникають рецидиви і прогресування ОГ [10].

У зв'язку з цим, метою дослідження стало вивчення клінічної та імунологічної ефективності нового імунотропного препарату «Алокін-альфа», діючою речовиною якого є цитокіноподібний пептид алоферон, у складі комплексної терапії рецидивного ОГ у ВІЛ-інфрікованих та хворих без імунодесіциту. Препарат запатентований в Україні, РФ, США, Японії, Південній Кореї і країнах Євросоюзу, виробник «Біофрарма» (м. Київ) за ліцензією фрармацевтичної компанії Геолік Фарм Маркетинг Груп - GFMG.

\section{Пацієнти і методи}

Загальне число обстежених і пролікованих хворих на рецидивний ОГ склало 56 людей, із них 16 ВІЛ-інфрікованих та 40 хворих без імунодесріциту.

Для репрезентативної вибірки хворі були поділені на чотири групи. До першої основної групи було включено 19 імунокомпетентних хворих на ОГ, до другої основної - 8 ВІЛ-інфікованих хворих з ОГ. Цим особам на фроні базисної терапії (щоденний прийом етіотропного засобу з міжнародною непатентованою назвою (МНH) валацикловір - 1,0 г всередину 2 рази на день впродовж 10-14 діб, з переходом на супресивну терапію по 0,5 г 2 рази на день впродовж 1 міс.) додатково призначали 3 підшкірні ін'єкції імунотропного препарату, який містить алоферон, в дозі 1 мг через день.
Першу і другу групу контролю склали 21 і 8 пацієнтів відповідно, яким призначали тільки зазначену базисну терапію.

Клініко-лабораторну оцінку протокольного та запропонованого нами лікування хворих здійснювали з врахуванням стадії ВІЛ-інфекції. Для цього дослідження пацієнти відбиралися методом довільної вибірки. Хворих досліджували протягом часу лікування і наступного амбулаторного спостереження протягом 3 міс.

У дослідження включали пацієнтів з клінічною картиною ОГ в період загострення, не більше ніж через 48 год від моменту появи висипань. Найближчі результати лікування оцінювали за зміною тривалості рецидиву ОГ. Тривалість рецидиву (час досягнення повної реепітелізації) оцінювали в добах. Віддалені результати лікування визначали за перебігом захворювання протягом 3 місяців амбулаторного спостереження: кількість наступних рецидивів за спостережуваний період; тривалість ремісій у добах.

Остаточну ефективність оцінювали за такими критеріями: «добрий ефект» - значне поліпшення клінічних симптомів захворювання; «задовільний ефект» - відповідно їх деяке поліпшення; «відсутність ефекту» - відсутність динаміки; «поганий есрект» - негативна динаміка.

Статистичну обробку отриманих результатів проводили за допомогою програмного комплексу STATISTICA 6.0 з використанням методу варіаційної статистики з визначенням достовірності за допомогою непараметричного методу Вілкоксона для незалежних сукупностей. Для порівняння двох незалежних груп використовували U критерій Манна-Уїтні. Розбіжності вважали статистично значущими при $р<0,05$ [11].

\section{Результати досліджень та їх обговорення}

Доповнення базисної терапії імунокомпетентних хворих на ОГ алофероном призводило до скорочення тривалості клінічних проявів порівняно з лікуванням тільки валацикловіром - $(5,9 \pm 0,6)$ проти $(8,6 \pm 1,2)$ доби ( $<<0,05$, табл. 1).

Найближчі наслідки лікування хворих на ОГ також переконливо демонструють перевагу доповнення базисної терапії алофероном. Так, не тільки зменшувалася частота рецидивів, але й вкорочувалася тривалість першого рецидиву після зазначеного лікування $(4,6 \pm 0,7)$ проти $(7,8 \pm 1,3)$ доби $(p<0,05)$. У пацієнтів контрольної групи базисна терапія суттєво не впливала на тривалість рецидивів (табл. 1).

Як видно з таблиці 1, доповнення базисної терапії алофрероном забезпечувало вкорочення рецидиву під час лікування та першого рецидиву після терапії значніше, ніж тільки під впливом лікування валацикловіром $(p<0,05)$. 
Таблиця 1

Вплив різних методів терапії на тривалість рецидиву ОГ в імунокомпетентних хворих (у добах, Мะm)

\begin{tabular}{|l|c|c|}
\hline \multicolumn{1}{|c|}{ Показник } & \multicolumn{2}{|c|}{ Групи хворих } \\
\cline { 2 - 3 } & $\begin{array}{c}\text { Базисна } \\
\text { терапія }(\mathrm{n}=21)\end{array}$ & $\begin{array}{c}\text { Базисна терапія + } \\
\text { алорерон }(\mathrm{n}=19)\end{array}$ \\
\hline Тривалість клінічних проявів попереднього рецидиву ОГ до лікування & $11,4 \pm 1,9$ & $12,0 \pm 2,0$ \\
\hline Тривалість клінічних проявів ОГ під час лікування & $8,6 \pm 1,2$ & $5,9 \pm 0,6^{*}$ \\
\hline Тривалість першого рецидиву ОГ після лікування & $7,8 \pm 1,3$ & $4,6 \pm 0,7^{*}$ \\
\hline
\end{tabular}

Примітка. * - достовірна різниця за критерієм Манна-Уїтні порівняно з хворими, які отримували тільки базисну терапію $(p<0,05)$.

Тримісячне амбулаторне спостереження за пацієнтами, які отримали тільки базисну терапію, вказувало лише на тенденцію до зменшення частоти наступних рецидивів ( $p>0,05$, табл. 2). Водночас допо- внення базисної терапії алофероном забезпечувало збільшення тривалості ремісії і достовірне зменшення частоти наступних рецидивів ОГ (в усіх випадках $p<0,05)$.

Таблиця 2

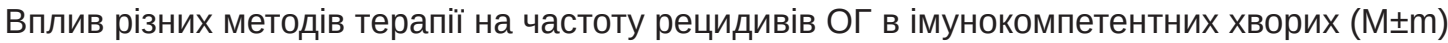

\begin{tabular}{|l|c|c|}
\hline \multirow{2}{*}{$\begin{array}{c}\text { Число рецидивів } \\
\text { протягом 3 міс. }\end{array}$} & Базисна терапія $(\mathrm{n}=21)$ & Групи хворих \\
\cline { 2 - 3 } & $1,23 \pm 0,20$ & $1,21 \pm 0,16$ \\
\hline до лікування & $0,67 \pm 0,18$ & $0,31 \pm 0,13^{*}$ \\
\hline після лікування & Базисна терапія + алорерон $(\mathrm{n}=19)$ \\
\hline
\end{tabular}

Примітка. * - достовірна різниця за критерієм Манна-Уїтні порівняно з хворими до лікування $(p<0,05)$.

При терапії алофрероном «хороший» ефрект (зниження частоти і тривалості рецидивів, зменшення їх тяжкості та подовження періоду ремісії) отримали у 52,6 \% хворих. Значно рідше констатували «задовільний» есрект (тривалість і тяжкість рецидивів практично не змінилася, але подовжився період ремісії) - 38,3 \% пацієнтів. В одиничних хворих $(9,1 \%)$ видимого клінічного ефректу не було. При такому способі лікування збільшення частоти та тяжкості рецидивів («поганий» есрект) не встановили у жодного пацієнта.

У той же час тільки базисна терапія валацикловіром протягом 7 днів забезпечувала «хороший» ефект лише у 19,0 \% осіб, «задовільний» - у 50,0 \%, «відсутній» -у 16,7 \%, «поганий» - у 14,3 \% пацієнтів з ОГ.

При оцінці тривалості клінічних проявів ОГ на фроні ВІЛ-інфекції у І-ІІ клінічних стадіях виявили її скорочення на фроні доповнення базисної терапії алофероном порівняно $з$ лікуванням тільки валацикловіром відповідно $(7,0 \pm 0,6)$ проти $(10,3 \pm 0,5)$ доби $(p<0,05$, табл. 3).

Поряд зі зменшенням частоти рецидивів після застосування апробованого цитокіноподібного препарату статистично вагомо скорочувалась й тривалість першого рецидиву ОГ після лікування, вона становила $(7,0 \pm 0,6)$ доби. У пацієнтів, лікованих лише валацикловіром, цей показник становив $(11,3 \pm 0,5)$ доби $(p<0,05)$.
III-IV клінічна стадія ВІЛ-інсрекції закономірно накладала свій відбиток на перебіг ОГ, що супроводжувалось і особливостями динаміки аналізованих показників під впливом різних методів терапії (табл. 3). Так, доповнення етіотропного лікування алофрероном забезпечувало достовірно коротшу тривалість клінічних проявів ОГ під час терапії - $(10,8 \pm 0,6)$ і $(13,5 \pm 0,7)$ доби відповідно, а також першого рецидиву після закінчення курсу лікування - $(9,8 \pm 0,4)$ і $(16,3 \pm 0,6)$ доби відповідно $(p<0,02)$. У пацієнтів контрольної групи базисна терапія суттєво не впливала на тривалість рецидивів.

Тримісячне амбулаторне спостереження за пацієнтами у І-ІІ клінічній стадії ВІЛ-інфекції, які отримали тільки базисну терапію ОГ, вказувало на відсутність будь-якої зміни частоти наступних рецидивів. Водночас доповнення базисної терапії алофероном забезпечувало збільшення тривалості ремісії і достовірне зменшення частоти наступних рецидивів ОГ ( $p<0,05$, табл. 4).

Упродовж 3 міс. спостереження за пацієнтами у III-IV клінічній стадії ВІЛ-інфекції, які отримали тільки базисну терапію ОГ, також не встановили якого-небудь впливу на частоту рецидивів ( $>>0,05)$. Доповнення ж базисної терапії апробованим цитокіноподібним препаратом забезпечувало збільшення тривалості ремісії і достовірне зменшення частоти рецидивів ОГ - від $(1,60 \pm 0,24)$ до $(0,60 \pm 0,24)$ разу на 3 міс. ( $p<0,05$, табл. 4$)$. 
Вплив різних методів терапії на тривалість рецидиву ОГ у хворих на ВІЛ-інфекцію у I-IV клінічних стадіях (у добах, $\mathrm{M} \pm \mathrm{m}$ )

\begin{tabular}{|c|c|c|c|c|}
\hline \multirow{3}{*}{ Показник } & \multicolumn{4}{|c|}{ Групи хворих } \\
\hline & \multicolumn{2}{|c|}{$\begin{array}{l}\text { ВІЛ-інсрекція, } \\
\text { І-ІІ клінічні стадії }\end{array}$} & \multicolumn{2}{|c|}{$\begin{array}{l}\text { ВІЛ-інфекцція, } \\
\text { III-IV клінічні стадії }\end{array}$} \\
\hline & $\begin{array}{c}\text { Базисна терапія } \\
(\mathrm{n}=4)\end{array}$ & $\begin{array}{c}\text { Базисна терапія } \\
+ \text { алофрерон } \\
(n=3)\end{array}$ & $\begin{array}{c}\text { Базисна } \\
\text { терапія } \\
(n=4)\end{array}$ & $\begin{array}{c}\text { Базисна терапія } \\
+ \text { алоферерон } \\
(n=5)\end{array}$ \\
\hline Тривалість попереднього рецидиву до лікування & $14,8 \pm 2,1$ & $14,7 \pm 2,2$ & $18,3 \pm 1,5$ & $18,8 \pm 1,2$ \\
\hline Тривалість клінічних проявів ГІ під час лікування & $10,3 \pm 0,5$ & $7,0 \pm 0,6^{*}$ & $13,5 \pm 0,7$ & $10,8 \pm 0,6^{*}$ \\
\hline Тривалість першого рецидиву після лікування & $11,3 \pm 0,5$ & $7,0 \pm 0,6^{*}$ & $16,3 \pm 0,6$ & $9,8 \pm 0,4^{*}$ \\
\hline
\end{tabular}

Примітка (тут і в табл. 4). * - достовірна різниця за критерієм Манна-Уїтні порівняно з хворими, які отримували тільки базисну терапію $(p<0,05-0,02)$.

Таблиця 4

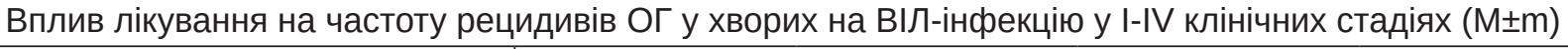

\begin{tabular}{|c|c|c|c|c|}
\hline \multirow{3}{*}{ Кількість рецидивів протягом 3 міс. } & \multicolumn{4}{|c|}{ Групи хворих } \\
\hline & \multicolumn{2}{|c|}{ ВІЛ-інфрекція, І-ІІ клінічні стадії } & \multicolumn{2}{|c|}{ ВІЛ-інфекція, III-IV клінічні стадії } \\
\hline & $\begin{array}{c}\text { Базисна терапія } \\
(\mathrm{n}=4)\end{array}$ & $\begin{array}{c}\text { Базисна терапія + } \\
\text { алоферон }(n=3)\end{array}$ & $\begin{array}{c}\text { Базисна терапія } \\
(n=4)\end{array}$ & $\begin{array}{c}\text { Базисна терапія + } \\
\text { алофрерон }(n=5)\end{array}$ \\
\hline до лікування & $1,25 \pm 0,25$ & $1,33 \pm 0,33$ & $1,75 \pm 0,48$ & $1,60 \pm 0,24$ \\
\hline після лікування & $0,50 \pm 0,29$ & $0,33 \pm 0,33^{*}$ & $1,25 \pm 0,25$ & $0,60 \pm 0,24^{*}$ \\
\hline
\end{tabular}

При терапії алофрероном «хороший» есрект (зниження частоти і тривалості рецидивів, зменшення їх тяжкості та подовження періоду ремісії) отримали у 50,0 \% хворих. Значно рідше констатували «задовільний» еорект (тривалість і тяжкість рецидивів практично не змінилася, але подовжився період ремісії) - 37,5 \% пацієнтів, не відзначили видимого клінічного ефректу від апробованого комбінованого лікування («відсутній» есрект) - 12,5 \% хворих. При такому способі терапії збільшення частоти та тяжкості рецидивів («поганого» есректу) не встановили у жодного пацієнта (табл. 5).

Таблиця 5

Результати різних методів лікування хворих на ВІЛ-асоційований ОГ

\begin{tabular}{|l|c|c|c|c|}
\hline \multirow{2}{*}{ Есект } & \multicolumn{4}{|c|}{ Групи хворих } \\
\cline { 2 - 5 } & \multicolumn{2}{|c|}{ Базисна терапія $(\mathrm{n}=8)$} & \multicolumn{2}{|c|}{ Базисна терапія + алосерон $(\mathrm{n}=8)$} \\
\cline { 2 - 5 } & абс. число & $\%$ & абс. число & \% \\
\hline Добрий & 2 & 25,0 & 4 & 50,0 \\
\hline Задовільний & 3 & 37,5 & 3 & 37,5 \\
\hline Відсутній & 2 & 25,0 & 1 & 12,5 \\
\hline Поганий & 1 & 12,5 & 0 & 0,0 \\
\hline
\end{tabular}

У той же час тільки базисна терапія валацикловіром хворих на ОГ протягом 7 днів забезпечувала «хороший» ефрект лише в 25,0 \% осіб, «задовільний» - у 37,5 \%, «відсутній» - у 25,0 \%. При цьому в 1 (12,5 \%) особи 3 ОГ на тлі ВІЛ-інфекції в IV клінічній стадії встановили збільшення частоти та тяжкості рецидивів («поганий клінічний ефрект»).
Таким чином, використання алоферону у комплексній терапії імунокомпетентних хворих на рецидивний ОГ і хворих на ВІЛ-асоційований ОГ за критеріями клінічної ефективності забезпечувало значніший терапевтичний ефект порівняно з валацикловіром, що застосовувався в контрольній групі. 


\section{Висновки}

1. Тільки базисна терапія імунокомпетентних хворих на рецидивний ОГ і хворих на ВІЛ-асоційований ОГ шляхом щоденного прийому етіотропного засобу валацикловіру по 1,0 г всередину 2 рази на день впродовж 10-14 діб не забезпечує вагомого клінічного ефекту.

2. Доповнення базисного лікування 3 підшкірними ін'єкціями імунотропного препарату алокін-альфа, який містить алоферон, у дозі 1 мг через день забезпечує скорочення тривалості клінічних проявів ОГ у хворих без імунодефріциту порівняно з терапією тільки валацикловіром $(p<0,05)$.

3. Найближчі наслідки лікування хворих на рецидивний ОГ у імунокомпетентних хворих також переконливо

\section{Література}

1. Barton S.E. Herpes management and prophylaxis / S.E. Barton // Dermatol. Clin. - 2008. - Vol. 16. - P. 799-803.

2. Герпес (этиология, диагностика, лечение) / И.Ф. Баринский, А.К. Шубладзе, А.А. Каспаров, В.И. Гребенюк. - М.: Медицина, 2006. $-272 \mathrm{c}$

3. Руденко А.О. Герпесвірусні інсекції людини - світова проблема / А.О. Руденко, Л.В. Муравська // Інфекційні хвороби. - 2001. - № 2. - С. 5-11.

4. Богадельников И.В. Роль герпесвирусной инсекции в организме человека / И.В. Богадельников // Сучасні медичні технології. - 2009. - № 3. - С. 57-61.

5. Исаков В.А. Патогенез и лабораторная диагностика герпеса: Руководство для врачей / В.А. Исаков, В.В. Борисова, Д.В. Исаков. - СПб: Лань, 2008. - 205 с.

6. Weber R. Decreasing mortality and changing patterns of causes of death in the Swiss HIV Cohort Study / R. Weber, M. Ruppik, M. Rickenbach // HIV Med. - 2013. - Vol. 14, N. 14. - P. 195-207.

\section{Referenses}

1. Barton, S.E. Herpes management and prophylaxis. Dermatol. Clin., 16, 799-803.

2. Barinskiy, I.F., Shubladze, A.K., Kasparov, A.A. \& Grebenyuk, V.I. (2006). Gerpes (etiologiya, diagnostika, lechenie) [Herpes (etiology, diagnostics, treatment)]. Moscow: Meditsina [in Russian].

3. Rudenko, A.O. \& Muravska, L.V. (2001). Herpesvirusni infektsii liudyny - svitova problema [Human herpesvirus infection - a world problem]. Infektsiini khvoroby -Infectious Diseases, 2, 5-11 [in Ukrainian].

4. Bogadelnkikov, I.V. (2009). Rol gerpesvirusnoy infektsyy v organizme cheloveka [Role of herpesviral infection in the body of a man]. Suchasni medychni tekhnolohii - Modern Medical Technology, 3, 57-61 [in Russian].

5. Isakov, V.A., Borisova, V.V., \& Isakov, D.V. (2008). Patogenez i laboratornaya diagnostika gerpesa: Rukovodstvo dlya vrachey [Pathogenesis and laboratory diagnostics of herpes: A guide for doctors]. St. Petersburg: Lan [in Russian].

6. Weber, R., Ruppik, M. \& Rickenbach, M. (2013). Decreasing mortality and changing patterns of causes of death in the Swiss HIV Cohort Study. HIV Med., 14 (14), 195-207.

7. Andreichyn, M.A. (2014). Problema VIL-infektsii v Ukraini i uchast likariv zahalnoi praktyky - simeinoi medytsyny $v$ yii vyrishenni демонструють перевагу доповнення базисної терапії алофероном: не тільки зменшувалася частота рецидивів, але й вкорочувалася тривалість першого рецидиву після зазначеного лікування $(p<0,05)$.

4. При оцінці тривалості клінічних проявів ОГ на фроні ВІЛ-інфекції виявили їі скорочення на фоні доповнення базисної терапії алофероном порівняно з лікуванням тільки валацикловіром. Поряд зі зменшенням частоти рецидивів ВІЛ-асоційованого ОГ після застосування апробованого цитокіноподібного препарату вагомо скорочувалась й тривалість першого рецидиву після лікування $(p<0,05)$.

7. Андрейчин М.А. Проблема ВІЛ-інфекції в Україні і участь лікарів загальної практики - сімейної медицини в ії вирішенні / М.А. Андрейчин // Інфекційні хвороби. - 2014. - № 4. - С. 7-12.

8. Інформаційний бюлетень № 46 «ВІЛ-інфекція в Україні». Київ, 2016. - МОЗ України. - 38 с. Режим доступу: http://phc.org.ua/ uploads/documents/c21991/b57cded7f4081d3ff549d8024a8d34fe.pdf

9. Клінічний протокол діагностики та лікування опортуністичних інфекцій і загальних симптомів у ВІЛ-інфікованих дорослих та підлітків / Затверджено наказом МОЗ України 13.04.2007 р., № 182 - 92 с. Режим доступу: http://phc.org.ua/uploads/documents/5416f7 /5e383386d320c87999c2801c80fcdcd8.pdf

10. Исаков В.А. Противовирусная терапия герпеса у больных с иммунодефицитами / В.А. Исаков, М.М. Сафронова, Ю.В. Аспель // Terra Medica. - 2009. - № 2. - C. 12-14.

11. Лапач С.Н. Статистические методы в медико-биологических исследованиях с использованием Excell / C.Н. Лапач, А.В. Чубенко, П.Н. Бабич. - Киев: МОРИОН, 2000. - 320 с.

[The problem of HIV in Ukraine and participating general practitioners - family medicine in its decision]. Infektsiini khvoroby - Infectious Diseases, 4, 7-12 [in Ukrainian].

8. Informatsiinyi biuleten № 46 «VIL-infektsiia v Ukraini» [Newsletter number 46 «HIV in Ukraine»]. (2016). Kyiv: - MOZ Ukrainy - Ministry of Health of Ukraine]. Retrieved from: http://phc.org.ua/uploads/documents/c21991/b57cded7f4081d3ff549d8024a8d34fe.pdf

9. Klinichnyi protokol diahnostyky ta likuvannia oportunistychnyx infektsii i zahalnykh symptomiv u VIL-infikovanykh doroslykh ta pidlitkiv / Zatverdzheno nakazom MOZ Ukrayiny 13.04.2007 r., № 182 [Clinical protocol for diagnosis and treatment of opportunistic infections and general symptoms in HIV-infected adults and adolescents / Approved by the Ministry of Health of Ukraine 13.04.2007., № 182]. Retrieved from: http://phc.org.ua/uploads/documents/5416f7/5e383386d320c8 7999c2801c80fcdcd8.pdf.

10. Isakov, V.A., Safronova, M.M. \& Aspel, Yu.V. (2009). Protivovirusnaya terapiya gerpesa u bolnykh s immunodefitsitami [Antiviral therapy of herpes in patients with immunodeficiency]. Terra Medica, 2, 12-14 [in Russian].

11. Lapach, S.N., Chubenko, A.V., \& Babich, P.N. (2000). Statisticheskie metody $v$ mediko-biologicheskih issledovaniyah $\mathrm{s}$ ispolzovaniem Excell [Statistical methods in medical and biological studies using Excell]. Kyiv: MORION [in Russian]. 


\section{EFFICIENCY ANALYSIS OF ALLOKIN- ALFA IN THE COMPLEX TREATMENT OF RECURRENT HERPES ZOSTER}

M.O. Sokolenko, V.D. Moskaliuk, A.A. Sokolenko, V.D. Sorokhan, Yu.I. Boyko

Higher State Educational Establishment of Ukraine «Bukovynian State Medical University»

SUMMARY. The aim of the work - to study the therapeutic efficiency of new immunotropic Allokin-alpha drug, the operating substance of which is a cytokine-like peptide of alloferon, in composition complex therapy of recurrent herpes zoster for HIV-infected patients and patients without an immunodeficit.

Patients and Methods. The quantity of examined and treated patients with recurrent herpes zoster were 56 people, including 16 HIV-positive and 40 patients without immunodeficiency. For a representative sample, patients were divided into four groups. The first main group included 19 immunocompetent patients with herpes zoster, the second primary - 8 HIV-infected patients with herpes zoster. These persons against the background of basic therapy (daily intake of etiotropic medication with international non-proprietary name (INN) valaciclovir - $1.0 \mathrm{~g}$ PO BID for 10-14 days, with the transition to the suppressive therapy of $0.5 \mathrm{~g}$ BID for 1 month) additionally administered SC injections of 3 immunotropic allokin-alpha, the main active ingredient of which is cytokine-like peptide alloferon, a dose of 1 mg each day. The first and second control group were 21 and 8 patients, respectively, who were administered only specified basic therapy.

Results. It has was found that the only basic therapy by means of daily administration of etiotropic valaciclovir $1.0 \mathrm{~g}$ PO 2 BID for 10-14 days in 16 patients with HIV-associated herpes zoster and 40 patients with herpes zoster HIV-negative status does not provide a meaningful clinical effect.

The addition by 3 SC injections allokin-alpha given at a dose of $1 \mathrm{mg} O D$ provides a statistically significant reduction in the duration of the clinical manifestations of herpes zoster in patients without immunodeficiency compared with valaciclovir therapy alone $(p<0.05)$.

Along with the reduction of recurrence after application of proven drug cytokine-like peptide statistical weight and decreasing the duration of first recurrence of HIVassociated herpes zoster after treatment, it was (7.0 \pm 0.6$)$ days. In patients treated only valaciclovir, the rate was $(11.3 \pm 0.5)$ day $(p<0.05)$.

Appropriate outpatient monitoring of patients in III-IV clinical stage of HIV disease who received only basic therapy of herpes zoster, also did not show any effect on relapse rate $(p>0.05)$. Supplement of the same basic therapy proven drug provided cytokine-like peptide increasing the duration of remission and a significant reduction in recurrence of herpes zoster - of (1.60 \pm 0.24$)$ to $(0.60 \pm 0.24)$ day for 3 months $(p<0.05)$.

Also, along with a decrease in the frequency of relapses HIV-associated herpes zoster in patients with III-IV clinical stage after applying proven drug cytokinelike peptide weighty and decreasing the duration of the first relapse after treatment - (9.8 \pm 0.4$)$ and $(16.3 \pm 0.6)$ days, respectively $(p<0.05)$.

Conclusions. Addition of base etiotropic treatment of herpes zoster provides reduction of duration of clinical displays immunotropic preparation allokin-alpha during treatment, reduction of duration of the first relapse after treatment, and also reduction of frequency of relapses both for HIV-infected patients and for patients without an immunodeficit.

Key words: HIV; herpes zoster; treatment; allokin-alpha.

Відомості про авторів:

Соколенко М.О. - асистент, Вищий державний навчальний заклад України «Буковинський державний медичний університет», sokolenko_maks@ukr.net

Москалюк В.Д. - д. мед. н., професор, Вищий державний навчальний заклад України «Буковинський державний медичний університет», vdmoskaliuk@rambler.ru

Соколенко А.А. - к. мед. н., асистент, Вищий державний навчальний заклад України «Буковинський державний медичний університет», alina_sokolenko@ukr.net

Сорохан В.Д. - к. мед. н., доцент, Вищий державний навчальний заклад України «Буковинський державний медичний університет», sorohan.vasyl@bsmu.edu.ua

Бойко Ю.І. - асистент, Вищий державний навчальний заклад України «Буковинський державний медичний університет», greenangel1@mail.ru

Information about authors:

Sokolenko M.O. - assistant, Higher State Educational Establishment of Ukraine «Bukovynian State Medical University», sokolenko_maks@ ukr.net

Moskaliuk V.D. - MD, Professor, Higher State Educational Establishment of Ukraine «Bukovynian State Medical University», vdmoskaliuk@rambler.ru

Sokolenko A.A. - PhD, assistant, Higher State Educational Establishment of Ukraine «Bukovynian State Medical University», alina_sokolenko@ukr.net

Sorokhan V.D. - PhD, associate professor, Higher State Educational Establishment of Ukraine «Bukovynian State Medical University», sorohan.vasyl@bsmu.edu.ua

Boyko Y.I. - assistant, Higher State Educational Establishment of Ukraine «Bukovynian State Medical University», greenangel1@mail.ru

Конфрлікт інтересів: немає.

Authors have no conflict of interest to declare.

Отримано 12.02.2017 p. 